\title{
Challenges and opportunities for culturally responsive leadership in schools: Evidence from Four European countries
}

Policy Futures in Education

202I, Vol. 0(0) I-28

(C) The Author(s) 2021

\section{(c) (i)}

Article reuse guidelines: sagepub.com/journals-permissions DOI: $10.1177 / 14782103211040909$ journals.sagepub.com/home/pfe @SAGE

Martin Brown' ${ }^{\circ}$, Herbert Altrichter ${ }^{2}$, Igor Shiyan³, María José Rodríguez Conde ${ }^{4}$, Gerry McNamara', Barbara Herzog-Punzenberger ${ }^{5}$, Irina Vorobyeva ${ }^{3}$, Valentina Vangrando ${ }^{4}$, Sarah Gardezi' ${ }^{\circledR}$, Joe O’Hara', Alexandra Postlbauer', Daria Milyaeva ${ }^{3}$, Natalia Sergeevna ${ }^{3}$, Sieglinde Fulterer ${ }^{2}$, Adriana Gamazo García ${ }^{4}$ and Lourdes Sánchez ${ }^{4}$

\footnotetext{
2Johannes Kepler University Linz, Linz, Austria;

${ }^{3}$ Moscow City University, Moscow, Russia;

${ }^{4}$ University of Salamanca, Salamanca, Spain;

${ }^{5}$ University of Innsbruck, Innsbruck, Austria
}

'EQI: The Centre for Evaluation, Quality and Inspection, DCU Institute of Education, Dublin, Ireland;

\begin{abstract}
Whether voluntary or enforced, increasing patterns of migration have significantly impacted schools by making them linguistically, culturally, religiously and ethnically more diverse than ever before. This increasing diversity requires school leaders to put in place mechanisms to ensure equity of participation for migration background students. Dimmock and Walker (2005) believe that school leaders need to play a vital role in promoting and sustaining an environment that embraces diversity and, by association, contributes to solving the macro problems of society. To accomplish this emerging role, there is a need for 'new approaches to educational leadership in which leaders exhibit culturally responsive organisational practices, behaviours and competencies' (Madhlangobe and Gordon, 2012: p. 177). This is all well and good in theory, but the current and historical context in which school leaders operate, together with the training and supports that are provided, influences, to a significant extent, how culturally responsive leadership can operate in practice. This study, which is part of a European Commission Erasmus + funded project entitled Supporting Culturally Responsive Leadership and Evaluation in Schools
\end{abstract}

Corresponding author:

Martin Brown, EQI, The Centre for Evaluation, Quality and Inspection, DCU Institute of Education, Dublin, Ireland.

Email: martin.brown@dcu.ie 
(CReLES), examines these assumptions by mapping out the factors and actors that can hinder and facilitate the flourishing of such practices in four European countries, Austria, Ireland, Russia and Spain.

\section{Keywords}

culturally responsive leadership, cultural responsivity, multiculturalism, migrant students, policy enactment

\section{Introduction and Background}

Whether voluntary or enforced, increasing patterns of migration have significantly impacted education systems by making them linguistically, culturally, religiously and ethnically more diverse than heretofore. The history of migration certainly started before the 20th century, and there are different trajectories between the continents and within various European regions (e.g. Bade, 1997; Lucassen et al., 2006: p. 11; Hoerder, 2002: p. 4-14). Concerning the more recent European migration history, Hoerder $(2002$, p. 7) notes that ' $[\mathrm{w}]$ hen power relationship changed, migratory directions reversed toward Europe. (...). Finally, in the decades since the 1950s, a new pattern emerged: transpacific migration, return migration from former colonies, multiple labour migrations, and refugee generation as well as distinct regional labour migration systems in the developing world'. With the beginning of this new migration system (Hoerder, 2002: p. 508-526), society became more diverse, and students with a migration background became more present and visible in society as a diverse group in itself. 'Students from migrant backgrounds are defined as newly arrived/first generation, second generation or returning migrant children and young people. Their reasons for having migrated (e.g. economic or political) may vary, as does their legal status - they may be citizens, residents, asylum seekers, refugees, unaccompanied minors or irregular migrants. Their length of stay in the host country may be short- or long-term, and they may or may not have the right to participate in the formal education system of the host country' (Eurydice, 2019: p. 29).

However, what has remained constant throughout the last number of years is that national and transnational organisations have consistently, with varying degrees of success, tried to find solutions designed to integrate students into the day-to-day life of schools. This is done to ensure that students do not feel alienated and ultimately have parity of opportunity to achieve at a similar level to that of their native peers (Brown, Altrichter et al., 2019). Indeed, there are many reasons to facilitate equity of participation in culturally diverse education systems, such as the democratic and educational logic of offering the best conditions for personal development to all human beings, the social logic of ensuring social heterogeneity, the economic logic of preparing students for the world of work, in particular, in countries that have a diminishing workforce and finally, the curtailment of identarian political movements.

To achieve such objectives, Dimmock and Walker (2005), among others (Magno and Schiff, 2010) are of the view that school leaders have a vital role in promoting and sustaining an environment that embraces diversity and, by association, contributes to solving the macro problems of society. Brown et al., 2019 further argue that increasing diversity in schools requires school leaders to act as bridge builders for students from various cultures and to embrace the concept of what is often referred to as culturally responsive leadership. Whilst there are varying definitions of culturally responsive leadership, more generally, the foundations for culturally responsive leadership are centred on 'those leadership philosophies, practices, and policies that create inclusive schooling 
environments for students and families from ethnically and culturally diverse backgrounds' (Johnson, 2014: p.148).

To accomplish this increasingly pressing role, Madhlangobe and Gordon (2012) state that there is a need for 'new approaches to educational leadership in which leaders exhibit culturally responsive organisational practices, behaviours, and competencies' (p.177). These are laudable objectives, yet the present and historical context in which school leaders operate influence to a significant extent how culturally responsive leadership can operate in practice (Brown, Altrichter et al., 2019). The purpose of this study, which is part of a European Unionfunded project entitled [Name Omitted for Peer Review], is to examine these challenges by mapping out the factors and actors that can hinder and facilitate the flourishing of such practices in four European countries (Austria, Ireland, Russia and Spain). The population diversity in these countries is based on the fact that they have majority native populations while immigrants from a range of different countries are diversifying their schools. The countries chosen for this study have similar patterns of migration yet varying levels of achievement by migrant students in transnational tests (Nayir et al. 2019). The Programme for International Student Assessment (PISA) country-wise trends show that migrant students in Ireland and the Russian Federation perform better than the Organisation for Economic Co-operation and Development (OECD) average. In Austria, their performance is lower compared to the OECD average. In Spain, no data is available for migrant students (Schleicher, 2019).

The article discusses the characteristics of culturally responsive school leadership that impact students' academic and psycho-social well-being from diverse cultural backgrounds. Leading on from this, the next section provides a comparative analysis of the hindering and facilitating policies and supports in the four countries participating that allow for the leadership of schools to ensure that the academic, personal, social and emotional development of culturally diverse students are on a par with their native peers. Finally, the article concludes with a discussion of the research findings derived from this analysis and provides recommendations for future research directions in culturally responsive leadership.

\section{Research Method}

Phase one of the research consisted of reviewing the international literature relating to how culturally responsive leadership (CRL) is conceptualised and defined. The literature review in this phase of the research led to eliciting meanings, achieving a depth of understanding and developing empirical knowledge about CRL (Bowen, 2009) while providing historical insights (Hodder, 2000) as to how cultural responsivity has gradually found its way into the discourse of national and transnational educational literature. While the term 'culturally responsive' guided this review, the review was conducted with an awareness of terms that are used in different contexts; for instance, 'intercultural competence' and 'globalisation'; 'cross-cultural', 'trans-cultural' and 'cultural pluralism' (Portera, 2008).

This was followed by a review of government reports, official websites and regulations associated with cultural diversity and leadership to paint an outline picture of the situation pertaining to each of the four partner countries. In phase two, the results were summarised and used as guiding categories to analyse the hindering and facilitating factors associated with embedding culturally responsive leadership practices in schools in each of the countries involved. 


\section{Research Phase I, part I: Making Meaning of the Concept of Culturally Responsive Leadership}

To adequately theorise the concept of culturally responsive school leadership, it is necessary to consider the interrelated concepts that constitute cultural responsivity and school leadership. While discussing cultural responsivity, the concept of culture is addressed by a number of authors such as Dimmock and Walker (2005), who elaborate on the various interpretations of culture by stating that:

Culture refers to the whole way of life of the members of a society or group. It includes how they dress what and how they eat, marriage customs and family life, their patterns of work, religious ceremonies, leisure pursuits and works of art. It is displayed and expressed through language, thought and action. It is also expressed through physical objects, such as works of art, books, icons, monuments and museums, and through social interaction such as how people relate to one another, make decisions and share experiences. It is the last of these-social interaction - that is perhaps of most significance for educational leadership. (p. 8)

The Ontario Ministry of Education (2013) also suggests that culture 'encompasses broad notions of similarity and difference and it is reflected in our students' multiple social identities and their ways of knowing and of being in the world'. Implicitly, then, the phrase 'culturally responsive' can be understood as having a positive, respectful, sensitive reaction to different expressions and habits of culture to ensure that 'all students are welcomed and accepted and inspired to succeed in a culture of high expectations for learning, schools and classrooms must be responsive to culture' (p.1).

Culture is also viewed as dynamic, fluid and changing, which implies that people's identities, which are constructed in their interactions or affiliations with different cultural constructs or understandings, are also changeable and changing. Additionally, actors have multiple and fluid cultural relationships and affiliations (OECD, 2016: p. 7). As a consequence, 'cultural responsivity' cannot mean to definitively link a person to a given version of culture, but rather materialises as preparedness to attend to different expressions of needs and to reflect one's own ways of coping with situations of difference.

School leadership has been a strong focus in the school effectiveness literature for a number of decades (Leithwood et al., 2020; Gumus et al., 2018; Hargreaves, 1995; Chapman et al., 2015). This broad body of literature has sought to examine the factors that contribute to effective school leadership. Some researchers, for example, Gurr (2015), are of the view that successful leaders exhibit specific personal attributes such as resilience, benevolence, honesty, openness, respectfulness and humility. These 'traits' or characteristics are seen as being critically important, and while there is some debate within the field of leadership studies as to the extent to which these traits are innate or learned (Gumus et al., 2018; Bush 2003), there is an agreement that the person of the leader is important in the definition of the leadership culture created in any educational setting. Various other models and definitions of 'successful' leadership have been proposed (Bush, 2003) that have suggested the presence, among other things, of features that include: setting high expectations; the embedding of a wide range of leadership practices - transformational, instructional and distributed; a focus on continuous learning for self and the entire school community; context sensitivity to optimise school success; and capacity to sustain success by engaging the school with the wider community (see, for example, Hallinger, 2011). Taking leadership characteristics such as 'contextsensitivity' and 'community engagement' into consideration, there is an obvious connection with the leaders' competence to cope with cultural diversity. Culturally responsive leaders are effective in 
culturally diverse situations and, according to Johnson and Fuller (2014), have the following features:

High expectations for student achievement incorporating the history, values, and cultural knowledge of students' home communities in the school curriculum, working to develop a critical consciousness among both students and faculty to challenge inequities in the larger society and creating organisational structures at the school and district level that empower students and parents from diverse racial and ethnic communities.

The literature on culturally responsive leadership is also informed by the fact that minority students, including students with a migration background, who are experiencing low academic achievement, are more likely to be experiencing behaviour issues in school and have a higher representation in special needs, compared to their peers (Vavrus and Cole, 2002; Gregory and Weinstein, 2008). A growing body of studies provides evidence that school leadership has a significant impact on student achievement (Beachum, 2011; Furman, 2012; Johnson, 2007) and, by association, students' achievement from a migration background (Nortvedt et al., 2020).

Magno and Schiff (2010), in their study on successful culturally responsive leadership, highlight the fact that such leaders, firstly, make institutional adjustments to welcome and support immigrant students with the implementation of administrative procedures. Secondly, they encourage academic achievement by assisting teachers in integrating immigrant experiences into their classes and lessons (p. 87). They also promote positive relationship among students, teachers, parents and the community around the school which enhances students' connectedness and parents' engagement with school (Khalifa, 2018) and are essential in the successful learning outcomes of students. Moreover, it is suggested in the literature that culturally responsive leaders can be described as 'critical, reflective, purposeful and fearless' (Lopez, 2015). They are also 'inclusive', 'culturally aware' and distribute leadership responsibilities within their organisations (Brown et al., 2019; Khalifa et al., 2016; Mitchell, 2015). However, while the traits for culturally responsive leaders are laudable in theory, there also exists a myriad of challenges to the implementation of these practices. It is this issue that forms the next part of the article.

\section{The challenges for culturally responsive leadership}

While defining the characteristics of culturally responsive school leaders, the literature also describes, in contrast, the position of the school, district and system-level personnel who consider the presence of students from diverse cultural backgrounds as 'an unwanted burden' (Cooper et al., 2009; see also Herzog-Punzenberger et al., 2020). Bias, fear, lack of cultural awareness, the absence of professional strategies and adequate support structures impede the ability of some educators to develop culturally responsive learning environments. Such educators are inclined to consider students from a different cultural background in a 'deficit' manner, blaming the students for what they lack. For example, Roybal (2018) describes a situation where teachers did not have the cultural proficiency to teach culturally diverse students effectively. In this example, a dispiriting climate emerged with conflict, misunderstanding, low teacher morale, high student indiscipline, with low student achievement becoming the norm. In such situations, the impact of culture on the classroom remains largely misunderstood, ignored or minimised. Germain to the creations of effective culturally responsive learning environments, Khalifa et al. (2016) are also of the view that school leaders should be provided with the professional development and skillset to build culturally 
responsive practices together with an understanding of how to lead reform in teacher practice, the school environment, and in the school's interaction with the community of parents and students.

On the other hand, even when professional learning is provided, Walker and Shuangye (2007) maintain that culturally responsive school leaders need to be dedicated to ongoing learning. They must also consciously understand issues around the diversity of cultures as well as being attuned to the values, beliefs and behavioural uniqueness of the students, teachers and others who comprise the school community. According to Dimmock (2003), leadership training also needs to be differentiated into different modes of professional learning depending on the career stage of the leader (e.g. newly appointed or experienced school leaders) as their needs can significantly differ at these different stages of the leadership cycle. Yet, even when the professional development to embed culturally responsive practices is provided to school leaders, there is also a possibility, as Kugler and West-Burns (2010) acknowledge, that system-level policies may not align with the best interests of culturally diverse populations.

There is also an emerging sensitivity to the complexity and challenging nature of leadership in a diverse cultural and demographic context (Moreland-Capuia, 2019). Hargreaves (2019), amongst others, challenges researchers and practitioners to address the difficulties facing even the most committed school leader and school system when seeking to find a mode of engagement with individuals and communities whose diverse needs are always challenging and at times mutually contradictory. In acknowledging this point, the exploration of the practice and support factors for culturally responsive leadership is at the heart of the [Name Omitted for Peer Review] project, and this will be examined later in this article.

\section{Research Phase I, part 2: Cultural Responsivity in the Four Countries Under Consideration}

\section{The foundations for cultural responsivity in Austria}

Migrants flow to Austria dates back to the 19th century initially due to political disaffection with their home countries and later to fill labour shortages (see, for example, Hahn, 2019; Verwiebe et al., 2019). However, the practice for the fixed-term migration did not work as many workers stayed for more extended periods and their families followed suit. At the end of the 1990s, a rethinking, particularly at the municipal level, took place which gradually accepted that Austria is a country of immigration and that the integration of immigrants is a task for public institutions (Herzog-Punzenberger, 2013).

The total Austrian population was 8,901,064 in 2020, 16.7\% of which were classified as foreign citizens (Statistik Austria, 2020a: p. 26). With 199,993 persons, Germans were by far the largest group of foreign nationals living in Austria (ibid., p. 29). The population with a migration background, that is, all persons, both of whose parents were born abroad, regardless of their nationality, was $23.7 \%$ in 2019 (ibid., p. 23). 24.4\% of all students in grade 8 had a migration background (BIFIE, 2020: p. 30) ${ }^{1} ; 8.2 \%$ of children below 15 years were foreign-born (Eurydice, 2019). The average share of school-age children with a first language other than German roughly amounted to a quarter, with some regions close to or above 50\% (Statistik Austria, 2020b).

In alignment with the consistent migrant flow, there is now an acceptance of diversity in Austrian law. According to the Austrian Federal Constitution Article 14 (B-VG, 2020), democracy, humanity, solidarity, peace and justice, openness and tolerance towards everyone regardless of their cultural affiliation, social status and financial background are fundamental principles of education in Austria (Eurydice, 2019). 
Admission to public school is open to all without distinction of birth, sex, race, estate, class, language and religion, and in other respects within the limits of the statutory requirements. The same shall apply mutatis mutandis to kindergartens, day homes and student hostels (B-VG, 2020, Article 14(6))

Due to the complexity of the issue of immigrant integration, the State Secretariat for Integration was set up in 2011 to centralise efforts and initiatives to facilitate the integration of immigrants in Austria. It has identified seven core areas of integration: language and education; work and vocation; law and values; health and social affairs, intercultural dialogue; sports and leisure; housing and regional integration (Hoekstra et al., 2017). Integration issues were transferred to the Ministry of Foreign Affairs in 2013 and are now (2020) administered by the Ministry for Women and Integration which is part of the Federal Chancellery.

Since the 1990's the strategy to cope with the growing diversity in schools stemming from immigration rested on three pillars:

1) German as a second language (optional).

2) Mother-tongue tuition (optional).

3) Intercultural learning as an instructional principle (implementation not monitored).

With a new minister in 2007 , new priorities were added, among them equity within the context of diversity. Consequently, a federal institute for interculturality, multilingualism and migration was set up to coordinate migration-related diversity issues in teacher education. ${ }^{2}$ Furthermore, a strategy was implemented to increase the participation of teachers in targeted inservice training and school improvement. Finally, the cooperation between schools and parents with migration backgrounds was to be professionalised. However, as no comprehensive evaluation of these measures has been carried out to date, it is hard to say how successful these initiatives have been.

Among the core issues relating to the integration of migrant students in schools, learning the language of instruction (German) has always been of prime importance. Since 2013, all students, regardless of their cultural affiliation, have their German language skills tested a year before starting school. Depending on the result of this test, children receive linguistic support to learn German in the last year of compulsory kindergarten. While before 2018, a more integrative approach to acquiring German was in place since the school year 2018/2019, students with a low German language proficiency are enrolled in special German support classes (Deutschförderklassen) for most of the school week (15 lessons at primary level and 20 lessons at the lower secondary level). For the rest of their school time, they are expected to join their age group mainstream classes (in subjects such as Sports and Arts). Furthermore, the Federal Ministry of Education allocates special funding for the provincial governments and boards of education to provide extra tuition to students whose German language skills need to be strengthened (Eurydice, 2019).

While supporting migrant students' proficiency in the language of instruction, their home language is considered the basis for learning the language of instruction and other foreign languages (European Commission, 2019). A special curriculum is designed to teach home languages, and many schools offer teaching in one or more of the 26 mother tongues most frequently present in the school system (BMBWF, 2020).

The ever-evolving cultural and linguistic diversity in Austria requires teachers and school leaders to develop competencies and skills to deal with multicultural and multilingual schools and classrooms. In Austria, the teacher competence profile 2015-2016 framework requires teachers to 
have the skills and knowledge needed to teach migrant students. However, so far, the ministry has not been successful in launching such an induction programme for student teachers. Universities have proved to be quite resistant to the recommendations of the National Quality Assurance body (Braunsteiner et al., 2014). This is in sharp contrast to many teacher training programmes in Germany $^{3}$ (There are, however, optional courses in teaching German as a second language in Austria, particularly at the master's level). The OECD Teaching and Learning International Survey (TALIS) reveals some consequences: only $31 \%$ of Austrian teachers stated that 'teaching in a multicultural or multilingual setting' was part of their training, and $41 \%$ of these teachers felt well or very well prepared for teaching in multicultural settings explain (OECD, 2018). Furthermore, and a central element for the creation of culturally responsive learning environments, 'Communicating with people from different cultures or countries' was the least frequently mentioned professional development theme available to teachers (16\%) (ibid., p.45).

In terms of formal leadership training, presently, leadership training is in a state of transformation when issues concerning the development of culturally responsive practices are concerned. Of the various Master's programmes for school management available in Austria, there is only one such module concerning culturally responsive school leadership that has been introduced; a module that is not obligatory for leadership positions (Kanape-Willingshofer et al., 2015).

\section{The policy enactment of culturally responsive leadership in the Austrian Education System}

School leaders are almost exclusively of Austrian mainstream origin (Nusche et al., 2010), While $8.1 \%$ of the teachers are from foreign origin, most of these are mother-tongue teachers or employed in private (international) schools as Austrian citizenship is a requirement for a permanent contract in the public school system. ${ }^{4}$ In the aftermath of the refugee-crises in 2015/16 teachers with refugeebackground were offered a requalification course to become regular teachers in the Austrian system. ${ }^{5}$ Some Austrian Teacher Education Institutions have tried to recruit students with migration background during the last decade; however, the discourse on diversifying the teaching force is not yet as intensive in Austria as it is in some other countries such as Germany and Great Britain (Schneider and Schmidt 2016).

Until recently, school leaders had very limited autonomy in choosing their teaching staff, deciding on their teachers' professional development or distributing leadership tasks among their teachers. However, in the Education Reforms since 2017, their role (for instance in staff recruitment) was strengthened and a school leadership profile was issued by the ministry (BMBWF, 2019). Furthermore, school leaders are not directly responsible for designing the school curriculum because there is a standardised national curriculum for both secondary and primary schools set by the central state. Though, as a result of a 'school autonomy' legislation, schools are allowed to change 5-10 per cent of the curriculum to write a 'school-autonomous curriculum'. School leaders usually have the main responsibility for organising processes for developing and implementing schoolautonomous curricula.

Finally, 'mobile intercultural teams' (MITs) have been set up under the responsibility of the Ministry of Education as a response to the refugee influx in 2015. These MITs are responsible for supporting schools, teachers, parents and students and complement school psychologists in implementing preventive measures, networking and counselling (Eurydice, 2019). At the school level, however, counselling is mainly the responsibility of the teachers. 


\section{The foundations for cultural responsivity in Ireland}

Ireland has experienced an upsurge in immigration since the mid-1990s in the wake of its economic growth (Eurydice, 2004). This migration flow has remained constant, and as of April 2019, 622,700 non-Irish nationals were residing in Ireland, accounting for $12.7 \%$ of the total population (Central Statistics Office, 2019). The proportion of young immigrants in the population (i.e. below 15 years of age) is $2.5 \%$. However, $12 \%$ of children under 15 in Ireland are foreign-born (Eurydice, 2019), which is among the highest in Europe. These statistics place Ireland on the top of the list of countries where promoting culturally responsive school leadership appears to be advisable. Indeed, the preamble to the Education Act 1998 takes cognisance of multiculturalism in Irish education.

... to ensure that the education system is accountable to students, their parents and the state for the education provided respects the diversity of values, beliefs, languages, and traditions in Irish society and is conducted in a spirit of partnership between schools, patrons, students, parents, teachers, and other school staff, the community served by the school and the state (Government of Ireland, p. iii)

In parallel to the concept of multiculturalism enshrined in legislation, the Irish government has also implemented several initiatives to integrate migrant children into the Irish school system by addressing the issues of multilingualism, multiculturalism and multi denominationalism. The two most significant measures have been the appointment of a Minister of State at the Department of Justice with responsibility for Integration, Immigration and Equality and the development and implementation of National Action Plans for social inclusion (Department of Education [DES], 2011). These significant steps have led to the provision of English language support teachers for schools that provide exclusive coaching in English language skills to children whose first language is not English. Additionally, professional development for mainstream teachers to support children's learning in the second language context is also provided (DES, 2011; Eurydice, 2004). According to the OECD (2016), the training provided in the English language supports is widely available across Ireland and much used by teachers. However, there are still very limited culturally responsive professional development opportunities for mainstream teachers as well as initial teacher education programmes for teaching in a multicultural school environment (Nayir et al., 2019).

In terms of Initial Teacher Education programmes, specialised modules are organised in some teacher education settings in Ireland, providing guidance and teaching materials emphasising the importance of an intercultural approach in education (Eurydice, 2004).

\section{The policy enactment of culturally responsive leadership in the Irish Education System}

At a policy and regulation level, the Education Act shares a broad expectation of the school principals to ensure inclusivity and equity, requiring them to

...be responsible for the creation, together with the board, parents of students and the teachers, of a school environment which is supportive of learning among the students and which promotes the professional development of the teacher (Government of Ireland, 1998, p. iii)

In Ireland, a significant majority of teachers and school leaders come from majority ethnic white Catholic backgrounds (Darmody and Smyth, 2016; Devine, 2013). According to Keane and Heinz's (2015) study concerning the socio-demographic composition of post-primary initial teacher education entrants, $99 \%$ of entrants in postgraduate post-primary programmes were identified as 
White Irish, and 100\% specified either English or Irish as their first language. Additionally, one of the entry requirements to initial teacher education programmes in primary schools in Ireland is proficiency in the Irish language (Teaching Council, 2021) that is likely to preclude any potential candidate from a migration background. However, one initiative to enhance diversity among teachers relates to that of an initiative that was set up by the Department of Justice and Equality in collaboration with the Department of Education and Skills and Marino Institute of Education. This programme is for the purpose of upskilling teachers from immigration backgrounds so that they can gain employment in schools. The first cohort of 34 teachers from 17 different countries has completed the programme to date (McGinnity et al., 2020).

Schools in Ireland have considerable autonomy with respect to how they meet the needs of immigrant children (Eurydice, 2004). It is at the discretion of the school leadership team to employ whatever strategies for improvement that they deem necessary in the context of their school. However, Looking at Our School (DES, 2016), the quality frameworks for primary and post-primary schools feature fostering a commitment to inclusion, equality of opportunity and the holistic development of each student as one of the indicators of quality leadership practice. In a way, although not explicitly stated, school leaders are made aware of their responsibility to be culturally responsive.

In terms of curriculum development and summative assessments, these quality instruments are mainly the responsibility of a state agency, the National Council for Curriculum and Assessment (NCCA) though schools manage formative assessments in secondary schools and most assessments apart from standardised tests in primary schools. Among twenty-four statements of learning for the lower secondary Junior cycle curriculum, one relates to cultural responsivity; the learner 'appreciates and respects how diverse values, beliefs and traditions have contributed to the communities and culture in which she/he lives' (NCCA, 2020). Similarly, one of the critical issues addressed in primary education is 'pluralism, respect for diversity and the importance of tolerance' in line with the changing profile of the population (DES, 1999: p.9). Nevertheless, it is the responsibility of school leaders to provide professional support to teachers to meet this challenge.

Despite the frequent acknowledgement of these themes, culturally responsive school leadership or managing multicultural schools are not included in any of the government-funded training programmes for school leaders. The Professional Development Service for Teachers (PDST), The Joint Management Body (JMB) and The Centre for School Leadership (CSL), however, offer some training programmes that include sessions on values, vision, equity, current educational issues, leading learning and the dynamics of change management where the issues of multicultural classes, social inclusion, and integration of migrant students can potentially come under discussion.

Along with school leaders and teachers, another essential position in schools is that of the Guidance Counsellor. They engage with students in a non-academic context and are quite often required to develop an understanding of their cultural values, beliefs to help them to benefit to the greatest extent possible from their engagement with the education system. This is explicitly stated in Section 9 of The Education Act 1998, which states that a school shall use its available resources to

(c) ensure that students have access to appropriate guidance to assist them in their educational and career choices

According to the Department of Education and Science (DESc), 'Schools are encouraged, therefore, to develop a comprehensive guidance plan as part of their overall school development plan' (2005, p.4). The guidance plan is to be developed in consultation with guidance counsellors. The schools may also seek support 'from the National Centre for Guidance in Education, the 
National Educational Psychological Service, the Department of Education and Science and other relevant agencies' (DESc, 2005: p.4) if they need to. The Guidance Plan encompasses three interlinked areas: students' personal and social development, educational guidance and career guidance.

In response to increasing cultural diversity, one nascent initiative to promote cultural diversity is the opening of Community National Schools (Education and Training Board Ireland, 2020) and Educate Together schools, mostly in urban areas of Ireland run directly by the State rather than Churches. There are one hundred and twenty-three schools where children are provided with equal learning opportunities in a setting of diversity and inclusion. The distinctive feature of these schools is their multi-belief and values education curriculum, Goodness me, goodness you. Through this curriculum, children learn to appreciate other children's religions and beliefs and engage in interbelief dialogue.

\section{The foundations for cultural responsivity in Russia}

The Russian Federation appeared on the world map as an independent state at the end of 1991, when the Soviet Union dissolved. Even as it grappled with massive political and economic upheaval, Russia suddenly found itself home to a large number of 'immigrants' from former Soviet states (Chudinovskikh and Denisenko, 2017). Simplification of immigration rules and later, the introduction of citizenship rules allowing citizens of the former Soviet countries to obtain Russian citizenship on meeting the necessary criteria resulted in a further upsurge in immigration to Russia in the 2010s. As of January 2020, the population of Russia is 146,745,098, and 81\% comprises ethnic Russians (Russian Federal State Statistics Service, 2020). With a sizeable percentage of other ethnic groups, the population aged 14 years and younger represent $18 \%$ of the total (UNESCO Institute for Statistics, 2017).

The Federal legislation on education taking account of this situation accentuates the principles of equality and inclusiveness in Paragraph 4, Part 1 of the Article 3, of the Federal Law 'On Education in the Russian Federation',

- Ensuring the right of everyone to education and non-discrimination in the field of education; and

- The adaptability of the education system to the level of training, developmental features, abilities and interests of an individual.

Paragraph 27, Article 2 of this Law defines the concept of 'Inclusive education':

- Ensuring equal access to education for all students, taking into account the diversity of special educational needs and individual opportunities.

Equal access to education is emphasised in Part 2, Article 78 of the Federal Law 'On Education in the Russian Federation' as well,

Foreign citizens have equal rights with citizens of the Russian Federation to receive pre-school, primary general, basic general and secondary general education, as well as vocational training... on an open and free basis. 
Furthermore, according to Article 68 of the Constitution of the Russian Federation, the Russian language is the state language of the whole territory of the Russian Federation and is also the language of instruction in schools. There are several articles in 'the Law on Languages' that allow the use of other languages in schools. It is the right of the citizens of the Russian Federation

to receive preschool, primary general and basic general education in their native language from among the languages of the peoples of the Russian Federation, as well as the right to study their native language from among the languages of the peoples of the Russian Federation, including the Russian language as their native language, within the scope of languages provided by the education system. These rights are ensured by establishing the required number of educational organisations, classes, groups, as well as conditions for their functioning (Part 2, Article 14, Paragraph 4).

The law defines the choice of the language of instruction at all school levels of education on languages in Article 14, Paragraph 6:

The language or languages of instruction are specified by the local regulatory acts of an organisation offering educational services by implementing training programmes in accordance with the legislation of the Russian Federation. The free choice of the language of instruction or the native language among the languages of the peoples of the Russian Federation, [...] the state languages of the republics of the Russian Federation is exercised by parents (legal representatives) of under-aged pupils upon admission (transition) to preschool, accredited primary general and basic general educational programmes.

Paragraph 5 of Article 14 allows the possibility of receiving education in a foreign language:

Instruction may be conducted in a foreign language in accordance with the accredited training programmes and procedures prescribed by the educational authorities and local regulatory acts of educational organisations.

It is necessary to note that officially in the Russian education system, there are 58 native languages of the peoples of the Russian Federation, while 36 languages have the status of the state language in the regions and republics of the Russian Federation alongside the Russian language. Federal educational programmes are approved for 13 native languages.

Learning native languages that have the status of state languages in specific regions and republics is not mandatory for all schoolchildren except for the Republics of Bashkortostan, Tatarstan and Yakutia.

In other regions of Russia, there are programmes to support native languages and the personal development of students in a multicultural environment. For example, the Republic of Kalmykia has undertaken a programme for the conservation and development of the Kalmyk language and the preservation of the ethnic culture of the children by creating such an environment in the schools. ${ }^{6}$ In 2018, the Russian government established the Fund for Preservation and Study of the Native Languages of the Peoples of the Russian Federation, which aimed to support research on the languages of small-population peoples, develop language programmes and study guides and train as teachers of native languages.

The new Federal State Educational Standard defines the composition of educational programmes for all levels of school education. It consists of compulsory elements (including the basic curriculum requirements and the compulsory fields of study such as the Russian language, foreign languages, mathematics, history, politics and natural sciences) and the variable part that is aimed at responding to the individual needs of students (including their ethnic and cultural needs). Every school designs its curriculum, which is based on these state requirements. For 
primary school, the ratio between the compulsory and the variable elements of the curriculum is $80 \%-20 \%$.

Therefore, the variable elements of the curriculum ensure and expand the right of Russian citizens to learn their native languages, cultures and the history of their peoples.

As regards initial teacher education and continuous professional development (CPD) programmes, there are no such programmes at a national level that address the issues of social inclusion, multilingualism and multiculturalism.

\section{The policy enactment of culturally responsive leadership in the Russian Education System}

Most school principals in the Russian Federation belong to the majority ethnic group. School leaders spend most of their time on administrative and leadership tasks, including meetings, writing reports and responding to requests and much less time on curriculum and teaching-related tasks (Lenskaya and Brun, 2016). According to Part 2, Article 26 of the Federal Law dated 29 December 2012, No. 273- $\Phi 3$ 'On Education in the Russian Federation', the management of an educational organisation is carried out based on the principles of single-authority and collegiality. The combination of these principles is the foundation for leadership practices at any school. Therefore, the common type of leadership in Russian schools combines hierarchical and advisory management models. Furthermore, School principals do not generally have high visibility in the local community except for issuing public reports, which are also made available on the website of their schools.

School counsellors have a multifarious role (paragraphs 4 and 5, Part 3, Article. 28 of the Federal Law). They are required to carry out professional activities aimed at preserving the mental, somatic and social well-being of students and staff in the process of education and training and to promote the protection of the personal rights of children across school and community. Counsellors have to participate with the school administration in the planning and development of educational and correctional programmes of educational activities, taking into account individual, age and gender characteristics of students and in this way have a significant role in shaping the school environment as it applies to migration background students.

Pre-service and professional development opportunities that are available for the school leaders align with the policy expectations of their role. As such, most of the training programmes are aimed at developing the competencies of administrative and economic management. However, there are several training programmes for pre-service teachers to develop competencies required for teaching in multicultural classrooms, such as Moscow City University's Master's programme 'Teaching Russian in a multicultural learning environment'. However, there is no information on specifically designed professional development programmes on culturally responsive leadership, which may be considered as a current deficit of the teacher education system.

\section{The foundations for cultural responsivity in Spain}

From the 1990s, especially after 1997, Spain became a destination country for immigration. The migrants' influx continued to increase till 2007 while the migrants were mainly Europeans, Latin American and Africans, but soon after the 2008 crisis, the number of immigrants from Asia and Africa increased considerably (Izquierdo, et al., 2016). Spain has experienced large-scale immigration, as of January 2019, there are 502,3279 foreign residents' population (Instituto Nacional de Estadistica, 2020). Within this, $4.6 \%$ of school-age children are foreign-born (Eurydice, 2019). This 
low figure can be attributed to the fact that Spain automatically grants Spanish nationality to the children of immigrants born in Spain.

Article 2 of the Organic Law 8/2013, while outlining the purposes of this law, accepts 'recognition of the linguistic and cultural plurality of Spain and interculturality as an enriching element of society'. In acknowledgement of the diversity of school populations, the Education Act 2006 was modified and the Act on the Improvement of the Quality of Education was passed in 2013. This reform recognises the need to combine quality and equity in the provision of education (Eurydice, 2019). The preamble to the law states

At the beginning of the 21st century, Spanish society has the conviction that it is necessary to improve the quality of education, but also that this benefit must reach all young people, without exclusions... It is, therefore, necessary to attend to the diversity of the students and contribute equally to the new challenges and the difficulties that this diversity generates.

In the spirit of these laws, multi-professional Education Guidance teams are formed in some autonomous communities such as Castilla y León. Among other tasks, their responsibilities include providing the necessary resources to enable students to reach their highest personal, intellectual, social and emotional development regardless of economic, cultural, religious, gender and sexual diversity. This team has the authority to ensure educational equity by carrying out specific programmes, curricular or structural modifications and coordination of teaching/learning processes using the guidelines provided by the Ministry of Education as a general framework (Ministry of Education, 2010). The team provides educational guidance and counselling regarding educational equity to all members of the educational community.

In Spain, there is a greater emphasis on promoting the language of instruction so that students have equal access to education. Knowing and appropriately using the Spanish language is one of the aims of education (Article 17. Organic Law, 2013). One of the characteristics of the Spanish Education System is its linguistic plurality; students are required to learn the community language as well, sometimes as the language of instruction and sometimes as a co-official language, depending upon the regulation of the autonomous communities (Ministerio De Educación, 2010). To develop migrant students' proficiency in the language of instruction, special preparatory classes are organised, and as soon as possible, the timing of the preparatory classes is reduced, and students are encouraged to spend more time in mainstream classes with their native-born peers (Eurydice, 2019). Furthermore, where large migrant communities such as Moroccan and Romanian exist, students are offered classes in their home language in some Autonomous communities such as Morocco-Castilla La Mancha (Eurydice, 2019).

The Spanish government's National Institute of Educational Technologies and Teacher Training also places a particular emphasis on inclusive education, student diversity and intercultural education with the provision of professional learning programmes for teachers. These programmes focus on raising teachers' awareness of students' academic as well as social-emotional needs. Two of the Spanish autonomous regions that have large populations of immigrants from Morocco and Romania (the Communidad Autónoma de Castilla-La Mancha and the Communidad Autónoma La Rioja) organise the Arabic and Moroccan Culture Teaching Programme (LACM) and the Romanian Language, Culture and Civilization Teaching programme (LCCR) in collaboration with the Kingdom of Morocco and the government of Romania (Eurydice, 2019). Furthermore, Spain is also one of the countries where teaching assistants are also deployed not only to facilitate students' academic progress but also to support their overall feeling of well-being in the school (ibid., p.24). 
Primary and Secondary school curricula are established jointly by national and regional education authorities. The national Ministry of Education issues the main guidelines of the curriculum, such as which subjects should be taught in each stage and grade, and the regional educational authorities develop the curriculum (specific aims, contents and assessment) for each of their territories (Ministerio De Educación, 2011). Finally, intercultural education is also promoted as a cross-curricular theme in some communities such as Cataluña of which, the cross-curricular themes to be developed are also stated in the curricula of these communities (Eurydice, 2019).

\section{The policy enactment of culturally responsive leadership in the Spanish Education System}

Principals have a significant role in managing and organising learning in schools, along with organising human and financial resources. The overall style of school leadership in Spain is consultative, and the principal is considered 'primus inter pares'. Most of the school leaders in the country are Spanish by ethnic and cultural affiliation. Indeed, the multidimensional needs of migrant students are quite likely to pose challenges to school heads; therefore, top-level education authorities organise targeted initial and continuing training activities for school leaders. These training programmes usually include subjects such as school climate, commitment to diversity, the integration of immigrants, the use of new technologies and the opening up of schools to the educational community and the wider community (Ministerio De Educación, 2011). However, school leaders have no role in teachers' professional development and it is managed by regional educational administrations. Finally, all secondary schools have a counsellor, who usually is a psychology or pedagogy professional and whose title is 'Orientador/a' (Counsellor). Primary schools can also avail of specific counselling teams working at a regional level if they have counselling-related needs (student difficulties or diversity, special education needs).

\section{Research, Phase 2: Support and Practice Indicators to Facilitate in the Four Countries}

Bringing together the accounts of the somewhat differing situations in the four project countries, this section of the article provides a summary analysis of the indicators that can be utilised to evaluate culturally responsive leadership, not only in these countries but in the myriad of other countries trying to respond to such dramatic and fundamental challenges. These indicators can be divided into two broad categories, namely, support indicators and practice indicators.

Support indicators include the following:

1. National or regional level policies and regulations that acknowledge cultural diversity in schools and encourage social inclusion and equity;

2. national or regional institutions or agencies that plan and initiate programmes for the integration of migrant students in schools and community;

3. policy on the use of student first language and support for the language of instruction;

4. the availability of pre-service and continuous professional development opportunities in culturally responsive pedagogy and leadership and

5. designated school staff, for example, guidance counsellors that plan and implement academic interventions as well as psycho-social support for the migrant students in schools. 
Practice indicators include the following:

1. The style of leadership (a combination of distributed, transformational and instructional);

2. high visibility of school leadership in the local community;

3. the ethnicity of school leaders;

4. school leadership as curriculum leaders (responsible for designing, implementing and assessment of curriculum) and

5. managing and organising professional development of teachers. ${ }^{7}$

The next section provides, in a tabular format, a summary of the support and practice indicators that exist in each of the partner countries. Drawn from this, there follows an analysis of the critical elements of culturally responsive leadership that, we would suggest, are very relevant much more widely across the globe.

The above tables indicate that a pattern of both strengths and weaknesses relating to the place of culturally responsive leadership emerges in all four countries that can impact on thinking on this crucial policy area in many other countries. Indeed, when all of the above indicators are applied to the school education systems of the four partner countries, an interesting picture emerges in each case and collectively as it relates to Legislation; Supports to facilitate the integration of immigrant students; State Strategies for the language of Instruction and Professional Learning opportunities to enhance culturally responsive practices.

\section{Legislation}

In all four countries, there is overarching legislation supporting cultural responsivity by recognising the diversity and focusing on the principles of equity, social justice and equality. However, the actualisation of these principles varies within and between countries. Notably, the Spanish Organic Law seems to be more advanced than the other three partner countries as the language used shows not just the acceptance of diversity but also an appreciation of the phenomenon. Furthermore, the word 'culture' also appears only in the Spanish Organic Law, and it suggested, is a misunderstood term that can results in various interpretations by school leaders. Similarly, the vocabulary used in the Education Act (Ireland) is liable to varying interpretations, and the use of the word 'foreign' in the Russian regulation conveys the notion of 'othering'.

\section{Supports to facilitate the integration of immigrant students}

In Austria, Ireland and Spain, there are specific agencies to monitor and facilitate the integration of immigrant students. In the case of Spain, for example, regional guidance teams are available to every school in Spain that may be partly due to Spain being the longest-term host to large-scale immigration and, as a result, having put in place a better system to support cultural responsivity in schools. On the other hand, there is no information about such a support system in Russia. To review and enhance the efficacy of migrant support agencies and departments is an enormous undertaking. In Ireland, however, the Economic and Social Research Institute (ESRI) produces a nuanced research report, almost every year, on the integration of migrants funded by the Department of Justice and Equality. The report reviews the migrants' integration processes and policies in the crucial sectors of life, such as employment, education, income, housing, health and naturalisation, and exposes the weaknesses and strengths of the system. Similarly in Austria, the Statistical Yearbook on Migration and Integration provides a data basis for migration and 


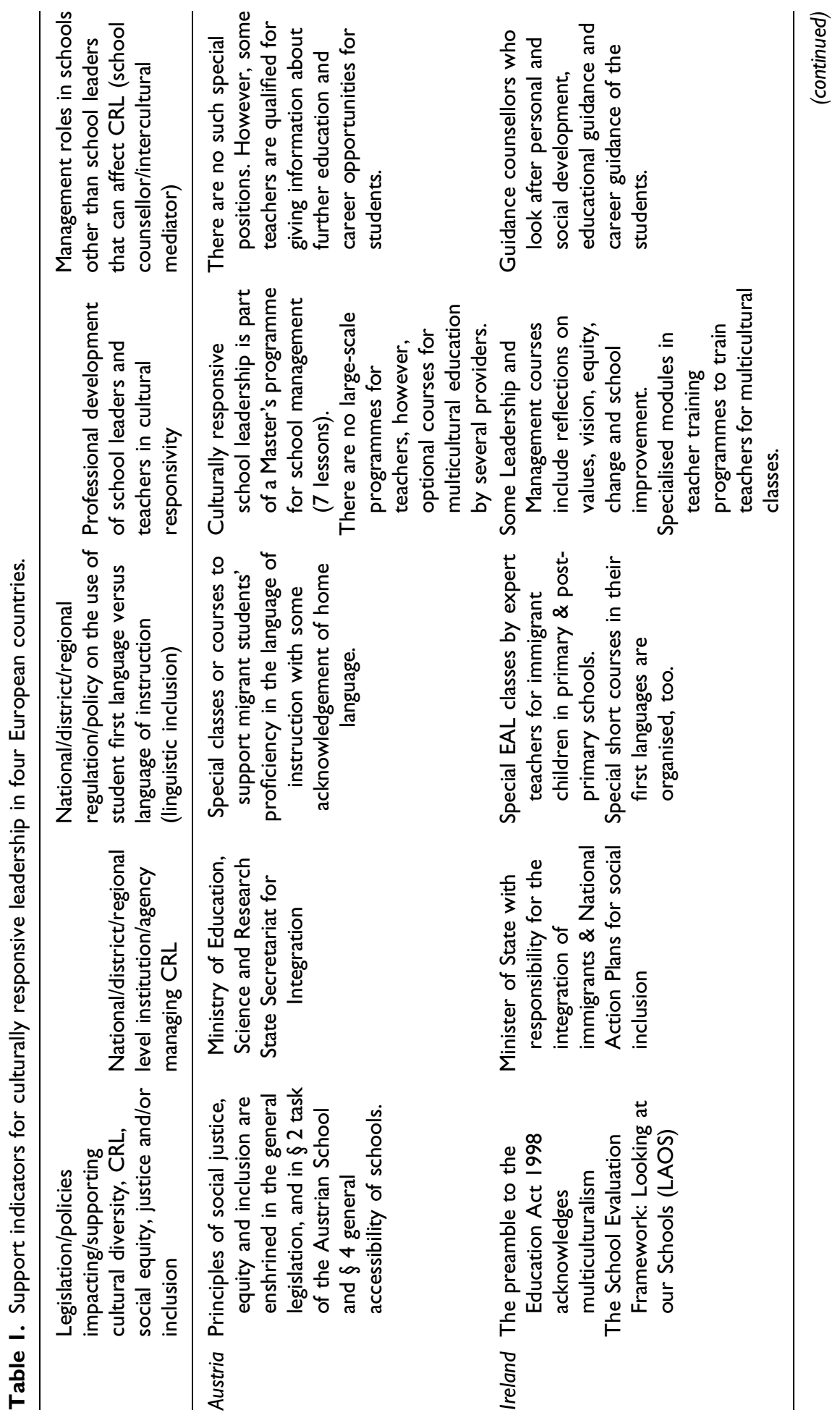




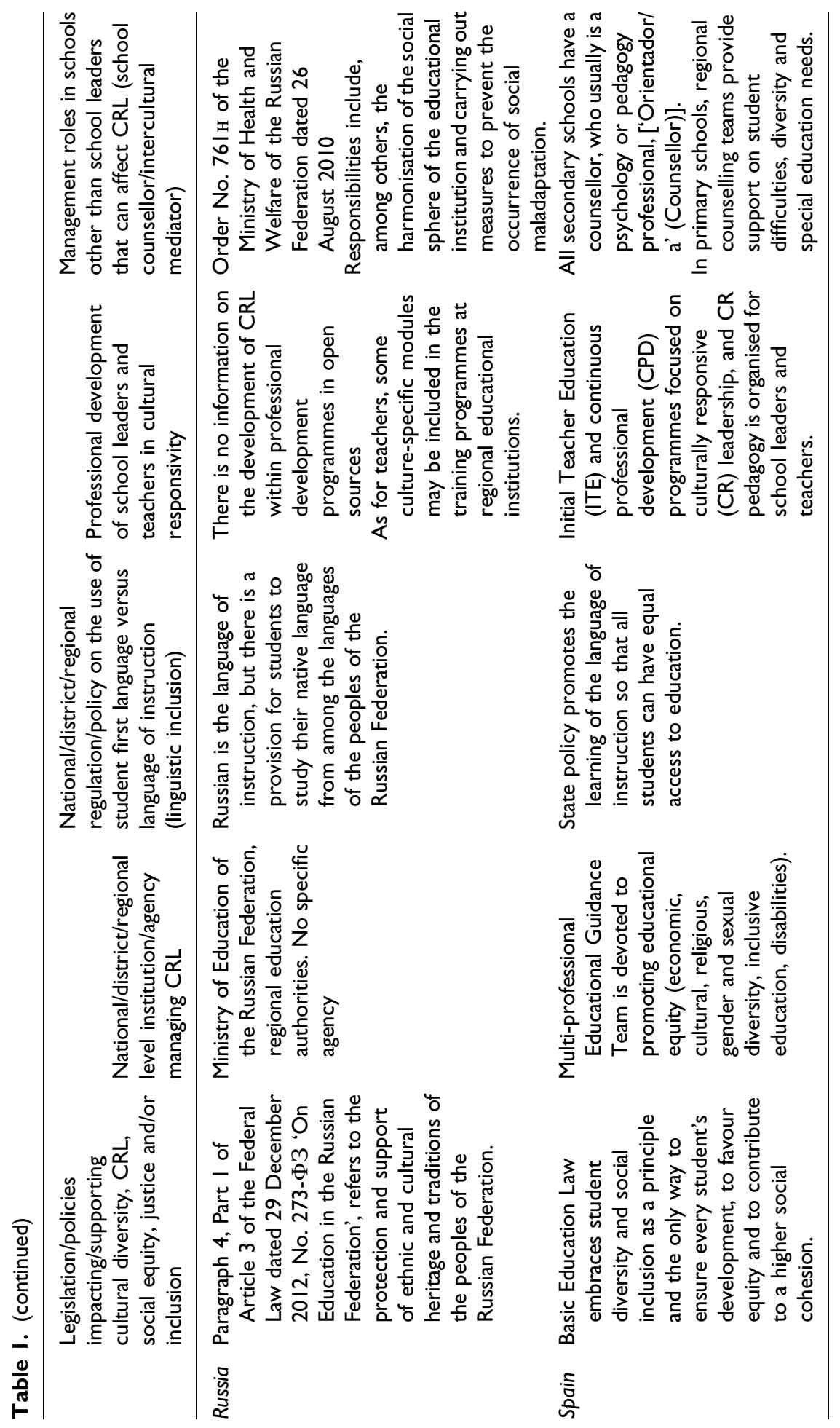




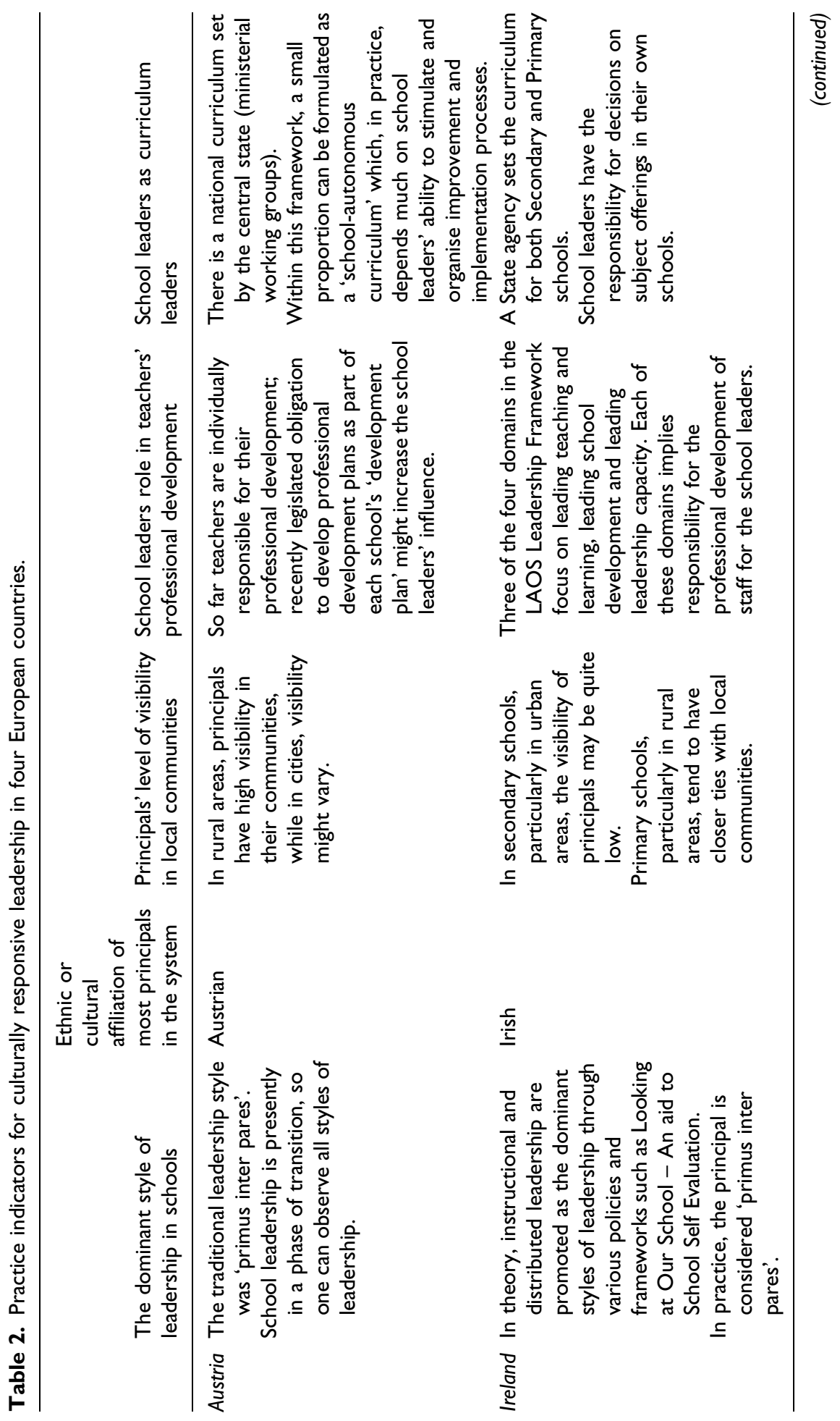




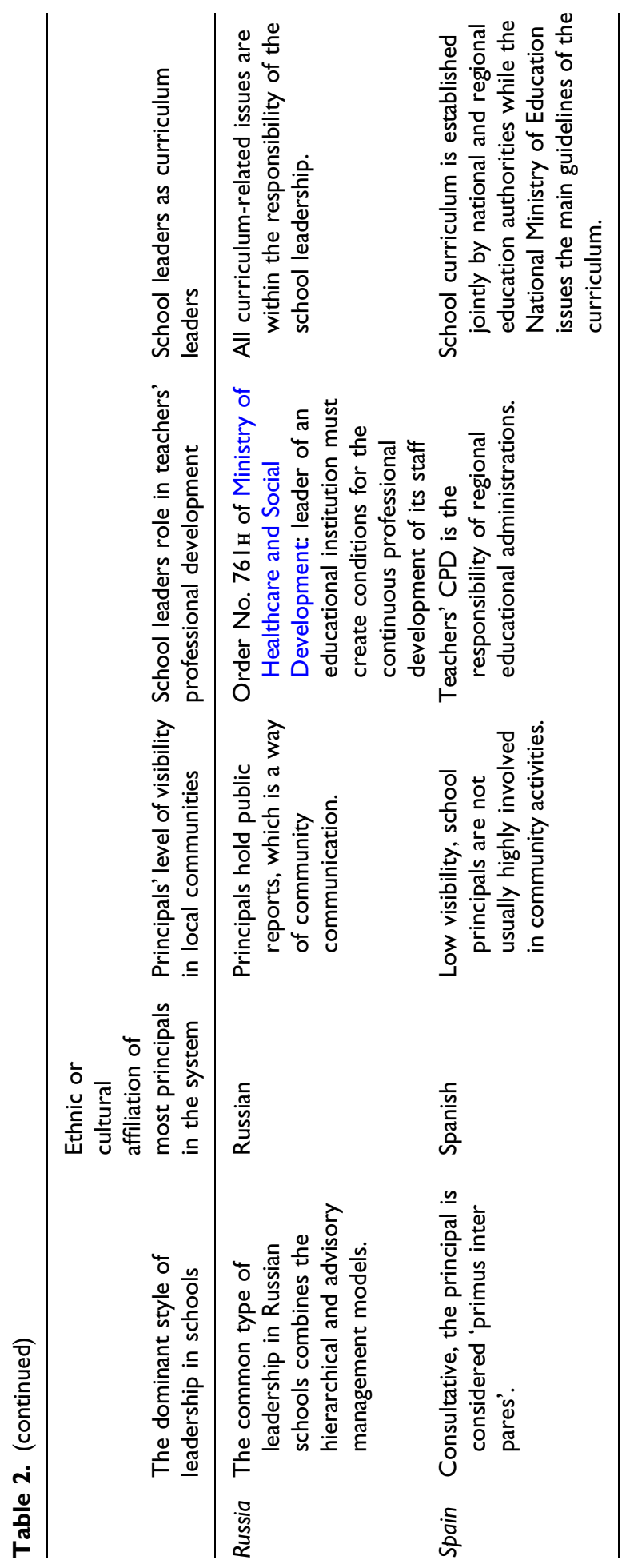


integration issues on the federal level (Statistik Austria, 2021), while the regular integration and diversity monitor of the City of Vienna offers an in-depth look on a provincial level (e.g. Stadt Wien 2020). Also the triannual national education report includes relevant indicators (Oberwimmer et al., 2019).

\section{State strategies for the language of instruction}

All four countries have strong systems as far as teaching the language of instruction is concerned to ensure inclusion in the learning process. Not only are extra classes organised to teach the language of instruction, but in some instances, teachers are also trained in second language pedagogy. In Austria, children's language proficiency is assessed even before the start of their school career so that they can be provided with needs-based language support. However, perhaps not ideally, this support is provided to students in special classes that are segregated from their native peers for large parts of the school day. Furthermore, school leaders and teachers in all four countries are encouraged to build their school-based culturally responsive strategies around state strategies of teaching the language of instruction. On the other hand, in Austria, Ireland and Spain, mother tongue or home languages are offered as optional subjects at the post-primary (secondary) level.

\section{Professional learning}

While pre-service and in-service professional learning opportunities for teachers in a culturally diverse classroom environment seem to be slowly increasing, there are still minimal opportunities for school leaders to enhance their capacities in culturally responsive leadership. For instance, in a Master's programme for school leaders in Austria, a short segment is allocated to cultural responsivity. The review of the existing leadership and teacher training programmes in Ireland and Russia also highlights the need to include new modules on cultural responsivity. On the other hand, Spain has exceeded the other partners in this area, with ITE and CPD programmes relevant to cultural responsivity available to both teachers and school leaders.

These initiatives, policies and practices seem to represent a minimum necessary positive response in some areas, particularly in terms of policy, while falling far short in other areas such as teacher training and development of school leaders. Other notable areas illuminated by the literature but hardly referenced in these four countries include culturally responsive assessment and community engagement.

\section{Discussion and Conclusion}

A review of the literature suggests that there are clear connections between effective school leadership and culturally responsive school leadership. The key characteristics of one are, in fact, the essential features of the other. However, culturally responsive leadership takes these features one step further. Personal traits, such as being humble, respectful, honest and open, are significant for all leaders. However, to be culturally responsive, she/he has to have the ability to empathise with all those who are different and at risk of being marginalised and also to put in place mechanisms to counteract the inequities being faced by students in their schools. A culturally responsive leader not only practices distributed and instructional leadership but ensures that every voice is heard, incorporates the cultural values and norms of the diverse student body and supports teachers' pedagogical practice in response to the needs of students from diverse backgrounds. 
Another significant issue relating to that of culturally responsive leadership concerns the composition of school leaders in all countries. In each of these countries, despite their everchanging demographics, teaching, and by association, the school leaders' workforce has remained relatively homogeneous because school leaders are usually former teachers who are selected to be school leaders after having attended some training in school administration. Several OECD reports and academic research literature also endorse this situation (see for example, Schneider and Schmidt 2016; Keane and Heinz, 2015; Nusche et al., 2010; OECD, 2018; ParkerJenkins and Masterson, 2013; Spanish Ministry of Education and Science, 2007). Teachers quite often come from a middle-class background and the majority population. In this regard, there is a need to diversify teaching, and school leadership as the presence of teachers and leaders from minority language and cultural backgrounds positively impacts not only migration background students' self-esteem and academic achievement but also native students' perceptions of immigrants (Darmody and Smyth, 2016). By sharing the same language, such leaders and teachers act as bridges between schools, students' families and migrant communities. Though the initiatives that Ireland and Spain have taken so far are appreciable, when compared with the extent of diversity in all four countries, these steps seem to have little effect if any on diversifying the teaching profession more generally. In this regard, some of the measures that Education systems can take to induct more teachers and school leaders from migration backgrounds may include modification of the entry requirements to initial teacher education by removing criteria such as in the case of Ireland, proficiency in the Irish language (a language that is rarely spoken if at all) that hinders potential teachers (of migration background) from entering the profession. As with the gender equity debate among the teaching profession, ITE providers can also be provided with targets to recruit a certain percentage of migrant student teachers or alternatively organise campaigns or career fairs to convince migrant parents and students to join the teaching workforce (Nusche et al., 2010).

The review also highlights the ramifications relating to the deficit portrayal of students from varied cultural and linguistic backgrounds and establishes a strong link between student learning and leadership. The literature stresses that when school leaders ensure that classroom instruction is conducted in a manner that is responsive to the students' home cultures, students' level of academic achievement improves, but if they receive a continuity of negative responses, it firstly affects their self-esteem and then their academic success (Brown, 2007). The negative or positive responses that migrant/minority students receive at school may also increase the rate of student drop-out, discipline infractions and damage teacher-student relationships. According to Schleicher (2019), among others, students with immigrant backgrounds face enormous challenges at school.

\footnotetext{
They need to adjust quickly to different academic expectations, learn in a new language, forge a social identity that incorporates both their background and their adopted country of residence - and withstand conflicting pressures from family and peers...It should thus come with no surprise that PISA data have consistently shown, in most countries, a performance gap between students with an immigrant background and native-born students (OECD, 2018: p.27).
}

The review of policy and practice within each of the partner countries indicates an awareness that the changing demographics, which is such a feature of recent times, implies an urgent set of challenges that must be considered. In an era of ageing populations in the developed world and immense migratory pressures in much of the world, vast population movements are a certain facet of the future. Economic competitiveness, not to mention social stability, is at stake. This seems well understood at a policy level. 
As always, however, as we see in Tables 1 and 2, turning policy into practice, rhetoric into reality is often problematic. In the four countries considered, while policies appear to be enlightened, the measures, in terms of resources, training, curriculum reform, diversity in the teaching force and the involvement of young people and their parents in meaningful ways in schooling remain underdeveloped, to say the least.

This research indicates that there is a great deal more to be done. The Eurydice Report (2019) for Integrating Students from Migrant Backgrounds into Schools in Europe: National Policies and Measures highlights the fact that a large number of migrant students leave school early because of the multitude of challenges to integrate into school environments and the education system at large. In conclusion, whilst the foundations for culturally responsive practices have been put in place via various legislative frameworks and system-level policies; more importantly, there is now, as evidenced in this review, a pressing need to translate policies into practice with, for example, the provision of compulsory professional development and Initial Teacher Education modules to allow for the flourishing of culturally responsive school leadership across jurisdictions. Certainly, the structure and content of leadership programmes need to be reviewed and updated to include modules on managing culturally diverse schools, facilitating the integration of students from diverse cultural backgrounds, celebrating interculturalism and supporting culturally responsive pedagogy.

In conclusion, most of the research about culturally responsive leadership focuses on school leaders' perceptions of policy, regulation and other supports in managing multicultural schools. In some cases, however, teachers are also interviewed or surveyed to learn about their experiences and needs in organising learning of the culturally diverse student population. One essential aspect of this research that is often ignored and receives limited coverage relates to the school experiences of students with a migration background to assess the impact of these policies and regulations on the school environment and such students' learning outcomes. Indeed, the notion of culturally responsive leadership will remain incomplete without reckoning students' lived experiences from reception to settling down and being part of a school or otherwise.

\section{Acknowledgements}

The authors wish to acknowledge that this research was made possible by funding through the Erasmus + project: Supporting Culturally Responsive Leadership and Evaluation in Schools (CReLES) (Project reference: 2019-1-IE01-KA201-051419).

\section{Declaration of conflicting interests}

The author(s) declared no potential conflicts of interest with respect to the research, authorship, and/or publication of this article.

\section{Funding}

This research was funded via the Erasmus+ project: Supporting Culturally Responsive Leadership and Evaluation in Schools (CReLES) (Project reference: 2019-1-IE01-KA201-051419).

\section{ORCID iDs}

Martin Brown (1) https://orcid.org/0000-0002-5436-354X

Sarah Gardezi (D) https://orcid.org/0000-0002-2234-3704

Lourdes Sánchez (1) https://orcid.org/0000-0002-9999-2593 


\section{Notes}

1. https://www.bifie.at/wp-content/uploads/2020/02/BiSt_UE_E8_2019_Bundesergebnisbericht.pdf (download 16.4.2020).

2. www.bimm.at

3. https://www.mercator-institut-sprachfoerderung.de/fileadmin/Redaktion/PDF/Publikationen/MercatorInstitut_Was_leistet_die_Lehrerbildung_03.pdf

4. https://www.oesterreich.gv.at/lexicon/B/Seite.991030.html

5. This research was part of the EU-funded project REQUAL (https://blog.hf.uni-koeln.de/immigrated-andrefugee-teachers-requal/).

6. The Development Programme of the National-Regional Education System as a condition for sustainable development of a child's personality within the context of multilingualism and multiculturalism in the October General Secondary School named after A. Durnev (2017-2020) https://oktabrsk08.kalm.eduru.ru/ media/2018/09/21/1219688778/PROGRAMMA_RAZVITIYA_NSO.pdf

7. These practice indicators are mostly themes and can be further split into more specific conceptual labels.

\section{References}

Bade K. J. (1997). From Emigration to immigration: The German Experience in the Nineteenth and Twentieth Centuries. In K. J. Bade and M. Weiner (eds.) Migration and refugees. Migration past, migration future: Germany and the United States. New York: Berghahn, pp.1-37.

Beachum F. D. (2011). Culturally Relevant Leadership for Complex 21st-Century School Contexts. In F.W. English (ed.) The SAGE handbook of educational leadership: Advances in theory, research, and practice. London: Sage, pp. 26-34.

BMBWF [Bundesministerium für Bildung, Wissenschaft und Forschung/Federal Ministry of Education, Science and Research of Austria] (2019). Schulleitungsprofil: Eine praxisbezogene Orientierung für effektives Schulleitungshandeln. Vienna: Bundesministerium für Bildung, Wissenschaft und Forschung (BMBWF). Available at: https://www.bmbwf.gv.at/public.html (accessed 23 December 2019).

BMBWF [Bundesministerium für Bildung, Wissenschaft und Forschung/Federal Ministry of Education, Science and Research of Austria] (2020). Additional support classes for German. Available at: https:// www.bmbwf.gv.at/en/Topics/school/krp/add_sup_cl_german.html (accessed 18 January 2020).

Bowen G.A. (2009) Document analysis as a qualitative research method. Qualitative Research Journal, 9(2), $27-40$.

Braunsteiner M. L., Schnider A. and Zahalka U. (2014). Grundlagen und Materialien zur Erstellung von Curricula. PädagogInnenbildung: Band 1. Graz: Leykam.

Brown M., Altrichter H., Nayir F., et al. (2019). Classroom assessment that recognises cultural difference-A European perspective. Available at: 10.13140/RG.2.2.14346.52164/2 (accessed 19 June 2020).

Brown M. R. (2007). Educating All Students: Creating culturally responsive teachers, classrooms, and schools. Intervention in School and Clinic, 43(1), 57-62.

Brown M., McNamara G., O'Hara J., et al. (2019) Evaluating the impact of distributed culturally responsive leadership in a disadvantaged rural primary school in Ireland. Educational Management Administration \& Leadership 47(3): 457-474. https://doi.org/10.1177/1741143217739360.

Bush T. (2003). Theories of Educational Leadership and Management (3rd edn). London: Sage.

B-VG (2020). Austrian Federal Constitutional Law. Available at: https://www.ris.bka.gv.at/Dokumente/Erv/ ERV_1930_1/ERV_1930_1.html (accessed 18 January 2020). 
Central Statistics Office. (2019). Population and Migration Estimates. Available at: https://www.cso.ie/en/ releasesandpublications/er/pme/populationandmigrationestimatesapril2019/ (accessed 14 February 2020).

Chapman C., Muijs D., Reynolds D., et al. (Eds.) (2015). The Routledge international handbook of educational effectiveness and improvement: Research, policy and practice. New York: Routledge.

Chudinovskikh O., and Denisenko M. (2017). Russia: A migration system with Soviet roots. The Online Journal of the Migration Policy Institute. Available at:https://www.migrationpolicy.org/article/ russia-migration-system-soviet-roots (accessed 8 June 2021).

Cooper C.W., Allen R. M., and Bettez S. C. (2009). Forming Culturally Responsive Learning Communities in Demographically Changing Schools. In CA Mullen. (ed.), The handbook of leadership and professional learning communities. New York: Palgrave Macmillan, pp. 103-114.

Darmody M. and Smyth E. (2016). Entry to Programmes of Initial Teacher Education. The Teaching Council, Dublin: The Economic and Social Research Institute.

Department of Education and Science. (2005). Guidelines for Second Level Schools on the Implications of Section 9(c) of the Edcuation Act 1998, Relating to Students' Access to Appropriate Guidance. Dublin: The Stationery Office.

Department of Education and Skills. (2011). Language Support for Migrants: A Value for Money Review of Expenditure on the Education of Migrant Students at Primary and Post-primary Level Who Do Not Speak English (or irish) as a first Language. Dublin: Department of Education and Skills.

Department of Education and Skills. (2016). Looking at our School 2016: A Quality Framework for Primary Schools. Dublin: Department of Education and Skills.

Devine D. (2013) Practising leadership in newly multi-ethnic schools: tensions in the field?, British Journal of Sociology of Education, 34 (3), 392-411. 10.1080/01425692.2012.722273.

Dimmock C. (2003). Leadership in Learning-Centred Schools: Cultural Context, Functions and Qualities. In M. Brundrett (ed.) Educational management research and practice. Leadership in education. London: Sage, pp. 3-22.

Dimmock C. and Walker A. (2005). Educational Leadership: Culture and Diversity. London: Sage.

Education and Training Board - Ireland (2020). Community National Schools. Available at: https://cns.ie (accessed 18 March 2020).

European Commission. (2019). Education and Training Monitor 2019: Austria. Brussels: European Commission. Eurydice. (2004). Integrating immigrant Children into Schools in Europe (Stand: June 2004). Eurydice survey. Available at: https://www.ncca.ie/media/3249/framework-for-junior-cycle-2015-en.pdf (accessed 19 June 2020).

Eurydice. (2019). Integrating Students from Migrant Backgrounds into Schools in Europe: National Policies and Measures. Available at: 10.2797/819077 (accessed 18 April 2020).

Furman G. (2012). Social Justice Leadership as Praxis. Educational Administration Quarterly, 48(2), 191-229.

Government of Ireland (1998). Education Act. Dublin: Stationery Office.

Gregory A. and Weinstein R. S. (2008). The discipline gap and African Americans: Defiance or cooperation in the high school classroom. Journal of School Psychology, 46(4), 455-475.

Gumus S., Bellibas M. S., Esen M., et al. (2018). A systematic review of studies on leadership models in educational research from 1980 to 2014. Educational Management Administration \& Leadership, 46(1), $25-48$.

Gurr D. (2015). A Model of Successful School Leadership from the International Successful School Principalship Project. Societies, 5(1), 136-150.

Hahn S. (2019). Es gab noch nie so viel Migration wie heute (früher waren die meisten Menschen sesshaft). In M. Haller and K. Apostle (eds.) Migration und Integration: Fakten oder Mythen? Siebzehn Schlagwörter auf dem Prüfstand. Vienna: Verlag der österreichischen Akademie der Wissenschaften, pp. 39-54. 
Hallinger P. (2011). Leadership for learning: Lessons from 40 years of empirical research. Journal of Educational Administration, 49(2), 125-142.

Hargreaves A. (2019). Leadership Ethics, Inequality \& Identity. Principal Connections, 23(1), 14-17.

Hargreaves D. H. (1995). School Culture, School Effectiveness and School Improvement. School Effectiveness and School Improvement, 6(1), 23-46.

Herzog-Punzenberger B. (2013). Ungleichheit in der Einwanderungsgesellschaft.. Bildung und Gesellschaft. Germany: Springer VS.

Herzog-Punzenberger B., Altrichter H., Brown M., et al. (2020) Teachers responding to cultural diversity: case studies on assessment practices, challenges and experiences in secondary schools in Austria, Ireland, Norway and Turkey. Educational Assessment, Evaluation and Accountability 32(3): 395-424. https://doi. org/10.1007/s11092-020-09330-y.

Hodder I. (2000). The interpretation of documents and material culture. In N. K. Denzin and Y. S. Lincoln (eds.) Handbook of Qualitative Research (2nd edn). London: Sage, pp. 703-715.

Hoekstra M. S., Kohlbacher J. and Rauhut D. (2017). Migration Governance in Three European Cities: New Local Paradigms?. In T. Lacroix and A. Desille (eds.) Migration, Diasporas and Citizenship Ser. International Migrations and Local Governance: A Global Perspective. New York: Palgrave Macmillan, pp. 17-38.

Hoerder D. (2002). Cultures in Contact: World Migrations in the Second Millennium. London: Duke University Press.

Instituto Nacional de Estadística. (2020). Population Figures and Demographic Census, Population Residents in Spain. Available at: https:/www.ine.es/dyngs/INEbase/en/listaoperaciones.htm (accessed 05 June 2020).

Izquierdo M., Jimeno J. F., and Lacuesta A. (2016). Spain: from massive immigration to vast emigration?. IZA Journal of Migration, 5(1), 1-20.

Johnson L. (2007). Rethinking successful school leadership in challenging U.S. schools: Culturally responsive practices in school-community relationships. International Studies in Educational Administration (Commonwealth Council for Educational Administration \& Management (CCEAM) 35 (3), 39-47.

Johnson L. (2014). Culturally responsive leadership for community empowerment. Multicultural Education Review, 6(2), 145-170.

Johnson L. and Fuller C. (2014). Culturally Responsive Leadership. New York: Oxford University Press.

Kanape-Willingshofer A., Altrichter H., Egger M., et al. (2015). Hochschullehrgang Schulmanagement an der Pädagogischen Hochschule Oberösterreich: Entwicklung von Kompetenzen für pädagogische Führung. In SG Huber and R Bosch Stiftung (eds.), Schule gemeinsam gestalten - Entwicklung von Kompetenzen für pädagogische Führung: Beiträge zu Leadership in der Lehrerbildung, Münster: Waxmann, pp. 304-309.

Keane E. and Heinz M. (2015). Diversity in initial teacher education in Ireland: the socio-demographic backgrounds of postgraduate post-primary entrants in 2013 and 2014. Irish Educational Studies, 34 (3), 281-301, 10.1080/03323315.2015.1067637.

Khalifa M. A. (2018). Culturally Responsive School Leadership. Cambridge: Harvard Education Press.

Khalifa, M. A., Gooden M. A. and Davis J. E. (2016). Culturally responsive school leadership: A synthesis of the literature. Review of Educational Research, 86(4), 1272-1311.

Kugler J. E. and West-Burns N. (2010). The CUS framework for culturally responsive and relevant pedagogy. Our Schools, Our Selves, 19(3), 211-218.

Leithwood K., Harris A. and Hopkins D. (2020). Seven strong claims about successful school leadership revisited. School Leadership \& Management, 40(1), 5-22.

Lenskaya E. and Brun I. (2016). Are Principals of Russian Schools Ready for Transformational Leadership. Voprosy Obrazovaniya/Educational Studies, 14, (2), 62-99. 
Lopez A. E. (2015). Navigating cultural borders in diverse contexts: Building capacity through culturally responsive leadership and critical praxis. Multicultural Education Review, 7(3), 171-184.

Lucassen L., Feldman D. and Oltmer J. (2006). Immigrant integration in Western Europe, Then and Now. In D. Feldman, L. Lucassen and J Oltmer (eds.), IMISCOE research. Paths of Integration: Migrants in Western Europe (1880-2004). Amsterdam: University Press, pp. 7-24.

Madhlangobe L. and Gordon S. P. (2012). Culturally responsive leadership in a diverse school. NASSP Bulletin, 96(3), 177-202.

Magno C. and Schiff M. (2010). Culturally responsive leadership: best practice in integrating immigrant students. Intercultural Education, 21(1), 87-91.

McGinnity F., Enright S., Quinn E., et al. (2020). Monitoring Report on Integration 2020. Dublin: The Economic and Social Research Institute.

Ministerio de Educación. (2010). Spanish Education System 2009. Available at: https://sede.educacion.gob.es/ publiventa/PdfServlet?pdf=VP15144.pdf\&area=E (accessed 05 June 2020).

Ministerio de Educación. (2011). Overcoming school failure: policies that work.: Spanish national report. OECD. Available at: https://www.oecd.org/spain/48631820.pdf (accessed 05 June 2020).

Mitchell C. A. (2015). Culturally Responsive School Leadership.: Exploring the Characteristics for Urban School Leaders. PhD Thesis, The University of Memphis.

Moreland-Capuia A. (2019). Cultural Responsivity. In Training for Change. Springer, Cham. https://doi.org/ 10.1007/978-3-030-19208-2 2

National Council for Curriculum and Assessment. (2020). Curriculum online: Statements of Learning Junior Cycle. Available at: https://www.curriculumonline.ie/Junior-cycle/Junior-Cycle-Subjects/Gaeilge/Statementsof-Learning/ (accessed 05 June 2020).

Nayir F., Brown M., Burns D., et al. (2019). Assessment with and for Migration Background Students-Cases from Europe. Eurasian Journal of Educational Research, 19 (79), 39-68.

Nortvedt G. A., Wiese E., Brown M., et al. (2020) Aiding culturally responsive assessment in schools in a globalising world. Educational Assessment, Evaluation and Accountability 32(1): 5-27. https://doi.org/ 10.1007/s11092-020-09316-w.

Nusche D., Shewbridge C. and Lamhauge Rasmussen C. (2010). OECD Reviews of Migrant Education: Austria 2010. Paris: OECD Publishing.

Oberwimmer K., Vogtenhuber S., Lassnigg L., et al. (Eds.). (2019). Nationaler Bildungsbericht Österreich 2018 - Band 1: Das Schulsystem im Spiegel von Daten und Indikatoren. Graz: Leykam. Available at: 10.17888/nbb2018-1.4 (accessed 30 June 2021).

OECD. (2016). Global Competency for an inclusive World. Paris: OECD.

OECD. (2018). Who aspires to a career in teaching? in Effective Teacher Policies: Insights from PISA. Paris: OECD Publishing. 10.1787/9789264301603-7-en.

Ontario Ministry of Education. (2013). Culturally Responsive Pedagogy Towards Equity and Inclusivity in Ontario Schools. Available at: www.edu.gov.on.ca/eng/literacynumeracy/inspire/research/CBS_ResponsivePedagogy. pdf (accessed 05 June 2020).

Parker-Jenkins M. and Masterson M. (2013). No longer 'Catholic, White and Gaelic': schools in Ireland coming to terms with cultural diversity. Irish Educational Studies, 32(4), 477-492.

Portera A. (2008). Intercultural education in Europe: epistemological and semantic aspects. Intercultural Education, 19(6), 481-491.

Roybal D. M. (2018). Influence of Culturally Responsive Education on School Climate within a Title School: Case Study. PhD Thesis, University of Phoenix.

Russian Federal State Statistics Service. (2020). Preliminary Estimated Population of the Russian Federation as of 1 January 2020. Available at: https://www.gks.ru/folder/12781. (accessed 05 June 2020). 
Schleicher A. (2019). PISA 2018: Insights and Interpretations. Available at: https:/www.oecd.org/pisa/PISA\% 202018\%20Insights\%20and\%20Interpretations\%20FINAL\%20PDF.pdf (accessed 19 July 2020).

Schneider J. and Schmidt C. (2016). Diversifying the Teaching Force in Transnational Contexts. Rotterdam: Sense Publishers.

Stadt Wien (2020). Integrations- und Diversitätsmonitor. Wien. Available at: https://www.wien.gv.at/menschen/ integration/pdf/monitor-2020.pdf (accessed 20 June 2021).

Statistik Austria (2020a). Statistisches Jahrbuch. Migration \& Integration: Zahlen Daten Indikatoren. Vienna: Statistik Austria.

Statistik Austria (2020b). Schülerinnen und Schüler mit nicht-deutscher Umgangssprache im Schuljahr 2018/ 19. Vienna: Statistik Austria.

Statistik Austria (2021). Statistisches Jahrbuch. Migration \& Integration: Zahlen Daten Indikatoren. Vienna: Statistik Austria.

Teaching Council Ireland. (2021). Initial Teacher Education (ITE) Primary. Available at: https:/www.education.ie/ en/Education-Staff/Information/-New-Teachers/-Initial-Teacher-Education-ITE-Primary.html.

The Spanish Ministry of Education and Science. (2007). School Leadership in Spain. OECD Country Background report: School Leadership. Available at: http://www.oecd.org/edu/schoolleadership (accessed 06 June 2021).

UNESCO Institute of Statistics. (2017). Russian Federation. Available at: http://uis.unesco.org/country/RU (accessed 19 July 2020).

Vavrus F. and Cole K. (2002). "I didn't do nothing": The discursive construction of school suspension. The Urban Review, 34(2), 87-111.

Verwiebe R., Fritsch N. S., and Liedl B. (2019). Der Arbeitsmarkt in Österreich. In W. Aschauer, M. BehamRabanser and O. Bodi-Fernandez (eds.), Die Lebenssituation von Migrantinnen und Migranten in Österreich: Ergebnisse einer Umfrage unter Zugewanderten Wiesbaden: Springer, pp. 113-153.

Walker A. and Shuangye C. (2007). Leader Authenticity in Intercultural School Contexts. Educational Management Administration \& Leadership, 35(2), 185-204.

\section{Author biography}

The authors are part of a research consortium that was formed as part of the Erasmus Plus funded project entitled: Supporting Culturally Responsive Leadership and Evaluation in Schools (CReLES). The consortium consists of five different Universities (EQI: The Centre for Evaluation, Quality and Inspection, School of Policy and Practice, DCU Institute of Education, Dublin, Ireland; Johannes Kepler University Linz, Austria; Moscow City University, Russia; University of Salamanca, Spain University of Innsbruck, Austria). 